\title{
GENERAL ASPECTS REGARDING THE EVOLUTION OF THE MANAGEMENT OF THE FORMS OF COOPERATION AND ASSOCIATION IN ROMANIA COMPARED TO THOSE IN THE EUROPEAN UNION
}

\author{
Popescu Alin ${ }^{1}$
}

\begin{abstract}
The article brings to the fore some general aspects regarding the evolution of the management of the forms of cooperation and association in Romania compared to those in the European Union. In Romania today it is necessary to make agricultural farms as profitable as possible, with markets which should be competitive and efficient in accessing various financial funds. The purpose of the article is to present the necessity of encouraging the association and cooperation of small farmers, as well as the problems that cause the Romanian producers association process to stagnate.
\end{abstract}

Keywords: association, cooperation, agricultural cooperation, farmers.

JEL Classification: $Q 13$

\section{Introduction}

In Romania, after the revolution of 1989, began the process of changing the economic system. The transition from the socialist economy to the transition economy, then to the market economy, required a long period of time, the transition being hampered by an inappropriate legislative and fiscal system, the private sector and the failure to adapt the dignitaries of that period to the new system.

The dismantling of the CAPs, followed by the dismantling of the IASs in the years after 1989, has led, in the spirit of increasing the interest of the population to regaining individual ownership, to the continuation of agricultural production on small areas and large informal surfaces. At the same time, the lack of fixed assets of a physical nature, necessary to sustain the agricultural productions, was accentuated.

Agricultural equipment and machinery have not been replaced by holders, some of them still operating today, but at very low yields.

Also during this period agriculture has been set before labor shortages, due to the removal of basic their agricultural production and their integration in the new bureaucratic structure or in other fields other than agriculture.

The lending system in its early form in the early years after 1989 did not agree to lending to agriculture due to the lack of guarantees due partly to the lack of clear ownership of land and the lack of other fixed assets of value that can be brought in the guarantee and on the other hand the presence of an unstructured economic branch in terms of quantitative levels and the structure of the salable agricultural production, lack of adequate conditioning and storage capacities.

At the same time, the process of leasing land for agricultural production to produce agricultural produce appeared, but the efficiency of their production was much lower than that of the European countries in the cases presented: obsolete and insufficient technology, lack of credit, lack of specialists and finally very low productivity.

\footnotetext{
${ }^{1}$ Assist PHD., 1 Decembrie 1918 University of Alba Iulia, Romania, Email:alin.popescu28@yahoo.com DOI: 10.29302/oeconomica.2017.19.2.7
} 


\section{Materials and methods}

Research methods and scientific tools used in carrying out this study are varied and adapted to the research field, and their alternation is subordinated to the objectives of the author. The main research method is content analysis. The paper starts with a study relying on scientific documenting in several stages: information on the sources, data collecting, study of documents, processing and grouping sources, evaluating and deep studying documents to reach the knowledge goal of the studied field.

At present, for small farms in Romania, it is important to intensify the process of agricultural cooperation that allows for increased production yield as well as the capitalization of production and thus the consolidation of a competitive agri-food sector under the competitive conditions of the market economy.

Small Romanian farmers, due to their development strategies, are faced with important decisions to choose how to behave in various conditions of uncertainty in trying to achieve far more profitable agricultural holdings with outlets, resistant to competition and efficiency in accessing various financial funds. (Otiman et al., 2013)

Compared to Romania, in the Western countries the agricultural co-operation has been developed and consolidated on the basis of the cooperative principles from the nineteenth century, with a continuity and natural evolution without syncope up to the present day.

In the countries of the European Union, the cooperative sector holds very high market shares, but quite different from one country to another and from product to product.

The following table no. 1 shows the agricultural production sold through cooperatives in the European Union countries, as a percentage.

Table 1

The number of cooperatives and their members in EU countries [\%]

\begin{tabular}{|l|c|c|c|c|c|c|c|c|c|}
\hline State & $\begin{array}{l}\text { Pork } \\
\text { meat }\end{array}$ & $\begin{array}{l}\text { Cattle } \\
\text { meat }\end{array}$ & Birds & Eggs & Milk & $\begin{array}{l}\text { Sugar } \\
\text { beet }\end{array}$ & Cereals & Fruits & Vegetables \\
\hline Denmark & 95 & 66 & - & 52 & 94 & - & 60 & $70-80$ & $70-80$ \\
\hline Germany & 3 & 28 & - & - & 62 & 80 & $45-50$ & 40 & 60 \\
\hline Greece & 27 & 2 & 15 & 2 & 20 & - & 49 & 57 & 3 \\
\hline Spain & 8 & 9 & 25 & 28 & 30 & 22 & 20 & 45 & 20 \\
\hline France & 85 & 30 & 30 & 25 & 50 & 16 & 70 & 45 & 35 \\
\hline Ireland & 66 & $15-20$ & 20 & - & 99,5 & - & 57 & 14,3 & 17,5 \\
\hline Italy & 13 & 12 & 35 & 48 & 40 & 69,5 & 20 & 43 & 13 \\
\hline $\begin{array}{l}\text { Luxemb } \\
\text { ourg }\end{array}$ & 37 & 38 & - & - & 81 & - & 79 & - & - \\
\hline Holland & 34 & 16 & 21 & 17 & 83 & 63 & 65 & 78 & 73 \\
\hline Austria & 20 & 25 & 70 & - & 90 & 100 & 60 & 18 & 28 \\
\hline Belgium & 20 & - & - & - & 53 & - & 30 & 75 & 85 \\
\hline Finland & 66 & 65 & 83 & 54 & 97 & - & 48 & - & - \\
\hline Sweden & 78 & 76,3 & - & 33 & 99 & 10 & 75 & 32 & 50 \\
\hline $\begin{array}{l}\text { Great } \\
\text { Britain }\end{array}$ & 28 & 10 & 25 & 18 & 67 & - & 24 & 67 & 26 \\
\hline
\end{tabular}

Source: Anca A, Organization and Representation of Agricultural Producers in Romania, Augusta Publishing House, 2005 
From the table above, it is noted that in countries such as the Netherlands, France, Denmark, Germany where the management of the cooperative sector is well organized, the percentage of agricultural production exploited through cooperatives is significant.

France has the most developed agricultural cooperative in Western Europe. In this country, the French trade unions have an essential role in the development and evolution of agricultural co-operation.

In the French cooperative system, the basic idea is that small and medium-sized households must find their place in the market. For this, they need to group together to share their product marketing capabilities, thus succeeding in creating a force to help them resist market economy laws. (Anca A, 2005).

In Italy, special emphasis is placed on co-operative systems linking the agricultural and manufacturing industries, including distribution, focusing on areas such as supplying agricultural producers with technical means, selected seeds, chemical fertilizers, collective sales, agricultural credit, etc. (Lapusan, 2002).

With nearly 4 million members in 2000, the German co-operative system has a very important economic activity through the supply cooperative system, providing farmers with $60 \%$ of the chemical fertilizers used, $35 \%$ of the number of agricultural machines and various tools and $66 \%$ fodder combined. Cooperatives produce over $80 \%$ of the flour intended for Germany, make up $85 \%$ of butter production, $75 \%$ of milk production, $72 \%$ of cheeses, $40 \%$ of fruit and vegetable production and $30 \%$ of meat. (Mateoc, 1999).

In the Netherlands, most cooperatives are specialized. Most Dutch farmers are members of at least 3 cooperatives such as credit cooperatives, supply cooperatives, milk production and processing cooperatives, cooperatives for the production of fodder potatoes, livestock cooperatives for meat and meat products, cooperatives auction for fruits, vegetables, flowers, etc. (Alexandri, 2006).

At the beginning of 2017, Romania has long been behind the Western European countries in terms of developing the associative sector in the field of agriculture, both in terms of diversity and market presence, with multiple barriers in association.

The weaknesses of the association in Romanian agriculture which position it in other European countries are determined by several disturbing factors.

An important factor is insufficient knowledge of the principles of association and how they operate in the agricultural sector. Principles such as the voluntary and open association, democratic control, economic participation, autonomy and independence, concern in the interests of associates are not sufficiently understood and applied. In this respect, action must be taken to identify ways to know and understand the information by potential associates, so that uncertainty, distrust and suspicion can disappear. Bodies with coordinating powers in agricultural structures have to become credible and visible on various ways of communication.

Another factor, which in many cases is the most powerful opponent in front of the association, is the mentality of the rural population in particular, which has been sealed by the way the old communist cooperative structures functioned, and which creates reticence at all that associative framework. Manifestation of perfect transparency, exercise of rigorous and rigorous control, communication and permanent transmission of information, presentation of good practice examples, study visits, are ways to demolish and overcome the inoculated mentality.

The lack of economic culture is another factor that prevents the realization of associations in agriculture. This makes the organization and management of associative structures not known. In this respect it is necessary to intervene in an organized framework of credible local entities that support debates on the organization and management of 
associations, the way of choosing the management of the associations and representing the interests of the associates.

Financial and fiscal factors are other obstacles to association. Lack of funds and double taxation are fears that interfere with the association. In this sense, it is necessary to intervene through legislative, stimulatory measures.

Besides these factors there are also coexistence issues caused by the poor support of local associations of the already established associations, the impossibility of lack of funds for affiliation to international representation bodies, the lack of a good marketing, the lack of knowledge about the financing from different sources. (Gazetadeagricultura.info)

After Romania's accession to the European Union, the Romanian agricultural producers can no longer be protected from the customs blockage, and thus the poor supply of their agricultural products is occupied by the European agri-food supply.

The low level of income of the Romanian farmers has made it impossible to control the factors influencing agricultural production such as climatic conditions, disease and pest attack, which caused the fluctuation of agricultural production from one year to the next, the reduced production destined for marketing the latter low and fluctuating incomes for farmers.

Increasing competitiveness in agriculture is largely conditional on the market capitalization of appropriate agricultural products both in quantitative and qualitative terms. The solution for this is the association of agricultural producers, although at present, a very low percentage of Romanian farmers are part of an associative form.

Although the advantages of associative forms in agriculture are known throughout the world, most Romanian farmers do not care when it comes to association.

The accumulation of production in agricultural holdings of optimal size as well as the diversification or specialization of agricultural production are closely related to the development of the association and cooperation relations that are formed along the technological flows of raw material production but also those concerning the processing and recovery of agricultural products. (Apiagorj.ro)

After the creation of the European Economic Community (CEEC), cooperative structures in the developed European countries have undergone mutations such as the organization of producers in the form of local, regional, federal, federal, federation and branch federations, integration of cooperatives into national companies or multinational corporations. (MADR, Zahi, 2003)

In the countries of the European Union, agricultural cooperatives are constituted through the participation of members with capital and are organized in various fields of agriculture, in the supply of farmers with means of production, taking over, processing and marketing of members' products as well as in order to provide agricultural services. In these countries, agricultural cooperatives are constituted by the fact that agricultural producers are scattered over large territories and fail to stand alone in the face of competitive requirements, the risks of selling products and making costly investments.

By developing the cooperative forms of economic organization of family farms it is possible to create the possibility of taking over the different functions of the family farms by cooperative enterprises specialized in the storage and marketing of the products or in supplying the agricultural holdings with the production factors necessary for the production activities. (Gavrilescu, 2000, Europa.eu)

In this way, agricultural holdings, especially small ones, can develop cooperative ties with large agri-food companies to take over agricultural raw materials under a contract.

The Western European agri-food system promotes cooperation in all forms of social organization of farmers from small, medium and large farms, agricultural cooperatives, cooperative societies to national or transnational agri-food firms. 
In Western European countries, the specialization of agricultural holdings is a very important feature of the production structure, caused by the technological, technical modernization but also by the deepening of the division of labor. The specialization involves the development of cooperation in all the links of the agri-food chains, starting from the supply of inputs, the production of agricultural raw materials, the storage, processing and marketing of the products (Baussard, 2005)

The countries with the largest co-operative network in the European Union are: Italy, Greece, Germany, Spain and France, but the highest economic power is held by agricultural cooperatives from countries such as France, Germany, Denmark, the Netherlands. (Dominique, 1996-2000)

By developing the cooperative forms of economic organization of family farms it is possible to create the possibility of taking over the different functions of the family farms by cooperative enterprises specialized in the storage and marketing of the products or in supplying the agricultural holdings with the production factors necessary for the production activities. (Gavrilescu, 2000, Europa.eu)

In this way, agricultural holdings, especially small ones, can develop cooperative ties with large agri-food companies to take over agricultural raw materials under a contract.

The Western European agri-food system promotes cooperation in all forms of social organization of farmers from small, medium and large farms, agricultural cooperatives, cooperative societies to national or transnational agro-food firms.

In Western European countries, the specialization of agricultural holdings is a very important feature of the production structure, caused by the technological, technical modernization but also by the deepening of the division of labor. The specialization involves the development of cooperation in all the links of the agri-food chains, starting from the supply of inputs, the production of agricultural raw materials, the storage, processing and marketing of the products (Baussard, 2005)

Greece, Germany, Spain and France, but the highest economic power is held by agricultural cooperatives from countries such as France, Germany, Denmark, the Netherlands. (Dominique - 1996-2000)

\section{Conclusions}

1. With all the benefits and positive effects that associative concepts would bring, they are strongly reticent in Romania. In our country, only $1 \%$ of farmers are part of an associative structure, which contrasts strongly with the data of other EU member states. By comparison, it should be noted that the European average is $34 \%$, with countries with an average of over $50 \%$ and even over $90 \%$ in highly developed countries.

2. Most of the Romanian farmers in the livestock sector have small and medium size holdings and do not have managerial experience and adequate knowledge of modern technology and production standards.

3. At the beginning of 2017, Romania has long been behind the Western European countries in terms of the development of the associative sector in the field of agriculture, both in terms of diversity and market presence, with multiple barriers in association.

4. At present, Romania faces the EU's competitive agricultural pressure on the part of the EU, and the low competitiveness of the processing sector is the main constraint in boosting export earnings.

5. The effects of globalization put the Romanian farmer in front of a fierce competition from the products made under conditions of efficiency much higher than the efficiency of his products. 


\section{Bibliography}

1. Alin Popescu, Teodor Mateoc, Camelia Mănescu, Gheorghe-Sebastian Sârb, Aurora Venig, Nicoleta Mateoc-Sîrb, Studies regarding cooperation and association of romanian agriculturists, Lucrări ştiinţifice, Seria I, vol. XVII (1), Management Agricol, pp. 189-194, Editura Agroprint, Timişoara, ISSN 1453-1410.

2. Alin Marcel Popescu, 2016, Teză de doctorat, Timișoara.

3. Alexandri, Cecilia A., colab., 2006, Integrarea europeană a piețelor agricole românești, Editura Terra Nostra.

4. Anca, A., 2005, Organizarea și reprezentarea producătorilor agricoli din România, Editura Augusta Artpress, Timișoara.

5. Dominique et Michele Fremy, 1996-2000, Guid RTL, Editura Robert Laffont, Paris.

6. Gavrilescu, D., 2000, Economie agroalimentară, Editura Expert.

7. Lăpușan, Al., 2002, Structuri agrare, Editura Banea Press, București.

8. Mateoc-Sîrb, Nicoleta, 1999, Exploatația agricolă, Editura Agroprint, Timișoara.

9. Păun Ion Otiman, Nicoleta Mateoc-Sîrb, Camelia Mănescu, 2013, Economie rurală, Editura Mirton, Timișoara.

***http://www.gazetadeagricultura.info/informatii-utile/580-asociatii-agricole/17074formele-de-asociere-in-agricultura.html.

***http://www.apiagorj.ro/download/Forme\%20asociative\%20ZMA.pdf.

***http://www.madr.ro/docs/agricultura/agricultura-romaniei-2015.pd 